\title{
Pembuatan Aplikasi Sebagai Penanda Mengenai Kampung Kreatif Tematik Pada Smart Branding Kota Bogor Berbasis Android
}

\author{
Raden Agung Pradana Rusdian, Agung Budi Prasetyo \\ Politeknik Negeri Media Kreatif \\ Jalan Srengseng Sawah Jagakarsa Jakarta Selatan
}

\section{INFORMASI ARTIKEL}

Sejarah Artikel:

Diterima Redaksi: 20 September 2020

Revisi Akhir: 21 November 2020

Diterbitkan Online: 15 Desember 2020

\begin{tabular}{l} 
KATA KUNCI \\
Media Informasi \\
Aplikasi Smart Branding \\
Smart City \\
Virtual Tour \\
Kampung Tematik \\
KORESPONDENSI \\
\hline
\end{tabular}

Email Mahasiswa : agungrusdian47@gmail.com

E-mail Dosen: agung@polimedia.ac.id

\section{A B S T R A C T}

The City of Bogor began to develop programs related to Smart City so that city management could run more easily with the help of technology. Bogor City made 6 dimensions in Smart City namely Smart Governance, Smart Branding, Smart Economy, Smart Living, Smart Society, and Smart Environment. One of the Offices related to the construction of the Bogor City Smart City is the Office of Communication and Information, Bogor City Encoding or commonly called Diskominfo. One of the developments is to make a media marker about tourist attractions, namely thematic creative villages. But the media is not enough to make people more interested and want to find out more deeply. That way, this navigation application is needed to complement the information media to be more interactive and have more value. The advantage of this application is that it can bring up virtual panoramic objects and also a location map that makes it easy for tourists to know the location to be addressed. This application is designed for Android-based Smartphones with a minimum specification KitKat.

\section{PENDAHULUAN}

Kota Bogor memiliki sebuah program yang bernamakan Smart City, Smart City sendiri terdiri dari enam dimensi, yaitu dimensi smart governance, smart branding, smart economy, smart living, smart society dan smart environment. Salah satu dimensi yang difokuskan oleh penulis ialah Smart Branding karena di dalam era informasi seperti saat ini, sebuah kota tidak lagi harus mampu memenuhi kebutuhannya hanya dengan memanfaatkan potensi lokal-nya, tetapi harus juga mampu menarik partisipasi masyarakat, baik dari dalam maupun luar daerah, serta pelaku bisnis dan investor untuk ikut mendorong percepatan pembangunan daerahnya.

Menurut Badan Perencanaan Pembangunan Daerah Kota Bogor (2020) Kampung tematik merupakan salah program prioritas wali kota dalam membentuk sebuah kampung wisata, pemerintah Kota Bogor yang mempunyai latar belakang menggali potensi wilayah dengan menggerakkan modal sosial yang ada di masyarakat. Kota Bogor untuk diarahkan menjadi potensi destinasi wisata Kota Bogor, disisi lain mempunyai tujuan untuk memunculkan destinasi wisata baru berbasis masyarakat setempat dengan merevitalisasi kampung-kota melalui perbaikan kawasan, meningkatkan kualitas lingkungan dan peningkatan ekonomi masyarakat.

Mengutip dari berbagai jurnal, umumnya sistem informasi dan navigasi objek wisata dijelaskan melalui media cetak seperti buku maupun booklet wisata hal ini yang menjadi kendala bahwa halnya masyarakat merasa kesulitan dalam mendapatkan informasi karena kurangnya media sejenis buku, majalah dan booklet yang tersedia dan juga dengan media informasi cetak masyarakat terkadang merasa bosan dan monoton. 
Menurut Parera dan Rachman (2015) pemanfaatan sistem navigasi objek wisata berbasis android bisa dijadikan alternatif bagi para turis lokal maupun mancanegara dalam mendapatkan informasi mengenai tempat wisata baik itu dari segi rute dan letak posisi dan fasilitas yang disediakan oleh pengelola objek wisata, mengingat smartphone android sudah banyak digunakan oleh masyarakat saat ini, menjadi peluang dalam mempromosikan wisata kampung tematik sangatlah besar dengan memanfaatkannya.

Penelitian terkait penggunaan aplikasi wisata menunjukan bahwa media penanda dalam aplikasi wisata mendapatkan respon sangat baik. Menurut Rahmandanu (2018) yang telah menguji penggunaan aplikasi wisata berdasarkan pengujian fungsionalitas admin dan pengguna yang dibuat dapat berjalan dengan baik. hasil persentase pengujian fungsionalitas admin dan pengguna menunjukkan $100 \%$, sedangkan pengujian usabilitas pada admin menunjukkan $73,3 \%$ dan pada pengguna menunjukkan $44,4 \%$ pengguna sangat setuju akan kemudahan sistem yang dibuat.

Dari penelusuran yang penulis lakukan di dalam google playstore mengenai aplikasi wisata navigasi ditemukan 9 aplikasi, misalnya dimana 3 merupakan milik pemerintah pusat/daerah dan sisanya merupakan milik swasta, informasi mengenai aplikasi yang telah diobservasi penulis menyimpulkan ada 3 fitur utama pada setiap aplikasi berupa gambar, informasi wisata dan peta lokasi wisata.

\section{TINJAUAN PUSTAKA}

\subsection{Media Penanda}

Kata media merupakan bentuk jamak dari kata medium yang dapat didefinisikan sebagai perantara atau pengantar terjadinya komunikasi dari pengirim menuju penerima (Heinich et.al., 2002;Ibrahim, 1997; Ibrahim et.al., 2001). Media merupakan sebuah alat yang mempunyai fungsi menyampaikan pesan (Bovee, 1997) AECT (Association for Education Communication Technologi) memberikan batasan media sebagai segala bentuk dan satuan yang digunakan orang untuk mengeluarkan pesan atau informasi.

Navigasi berasal dari bahasa Yunani yang terdiri dari kata navis yang artinya perahu atau kapal dan agake yang artinya mengarahkan, secara harfiah artinya mengarahkan sebuah kapal dalam pelayaran. Seiring perkembangan zaman kata navigasi tidak lagi digunkan dalam dunia kelautan tetapi sering juga digunakan di daratan dan udara. Navigasi adalah cara menentukan posisi dan arah perjalanan baik di medan sebenarnya maupun pada peta.Untuk mendalami ilmu navigasi, teknik dan pengetahuan alat bantu seperti kompas, Global Positioning System (GPS), Altimeter, dan peta sangat penting untuk di pelajari. Selain itu, hal penting lainnya yang harus di ketahui adalah membaca medan perjalanan dan tanda-tanda alam maupun buatan manusia sebagai penunjuk arah.

Dari definisi di atas dapat ditarik kesimpulan bahwa Dengan adanya aplikasi navigasi yang dapat menampilkan lokasi wisata kampung tematik melalui perangkat mobile membuat pengguna, khususnya wisatawan dapat mengetahui semua lokasi dan objek wisata dengan lebih cepat dan tepat. Pengguna juga dapat semakin memaksimalkan penggunaan dari smartphone yang dimiliki.

\subsection{Virtual Tour}

Virtual tour adalah simulasi dari lokasi yang ada, biasanya terdiri dari urutan video atau gambar diam.(C Meg. Nicola Building Virtual Tour; Considering simulation in the equity of experience concept. 2011) Hal ini juga dapat menggunakan unsur-unsur multimedia lainnya seperti efek suara, musik, narasi, dan teks. Ungkapan "virtual tour" sering digunakan untuk menggambarkan berbagai video dan media fotografi berbasis panorama menunjukkan pandangan tak terputus, karena panorama dapat berupa rangkaian foto atau panning Video rekaman . Namun, frase "tur panorama" dan "virtual tour" sebagian besar telah dikaitkan dengan wisata virtual yang dibuat menggunakan masih kamera . Wisata virtual tersebut terdiri dari sejumlah foto yang diambil dari satu sudut pandang . Kamera dan lensa yang diputar di sekitar apa yang disebut sebagai ada gunanya paralaks (titik yang tepat di belakang lensa di mana cahaya konvergen). (J Dusan; Rogue, Antonio; Leuski, Anton; Morie, Jacki; Traum, David. A Virtual Tour Guide for Virtual Worlds. 2009.)

\subsection{Kampung Tematik}

Kampung tematik belakangan ini terlihat menjamur dan menjadi daya tarik bagi masyarakat khususnya di Kota Bogor Seiring dengan dicanangkannya program pemerintah yang berupaya untuk merubah kampung-kampung kumuh menjadi kampung yang bersih, dengan salah satu programnya membentuk kampung tematik. Disamping itu kampung tematik ini bisa menjadi kampung destinasi wisata yang menarik bagi wisatawan domestik tidak menutup kemungkinan wistawan mancanegara juga akan tertarik mengunjungi kampung tematik.

Menurut Badan Perencanaan Pembangunan Daerah Kota Bogor (2020) Kampung tematik ini berbagai macam tema nya, tergantung potensi kampung yang bisa dikembangkan. Hal ini 
karena membentuk kampung tematik harus diupayakan mengangkat potensi.

\section{$2.4 U M L$}

UML (Unified Modeling Language) adalah sebuah bahasa yang berdasarkan grafik/gambar untuk memvisualisasi, menspesifikasikan, membangun, dan pendokumentasian dari sebuah sistem pengembangan software berbasis $\mathrm{OO}$ (ObjectOriented). (Sri Dharwiyanti, Pengantar Unified Modeling Language, 2003). UML sendiri juga memberikan standar penulisan sebuah sistem blue print, yang meliputi konsep bisnis proses, penulisan kelas-kelas dalam bahasa program yang spesifik, skema database, dan komponen-komponen yang diperlukan dalam sistem software.

\section{KONSEP PERANCANGAN}

\subsection{Alur Kerja}

Adapun rencana dalam pembuatan aplikasi navigasi ada tiga tahap yaitu; pra produksi yang dilakukan sebelum pembuatan karya, produksi yaitu tahap pembuatan karya, dan tahap pasca produksi adalah tahap pengujian setelah karya telah selesai dibuat.
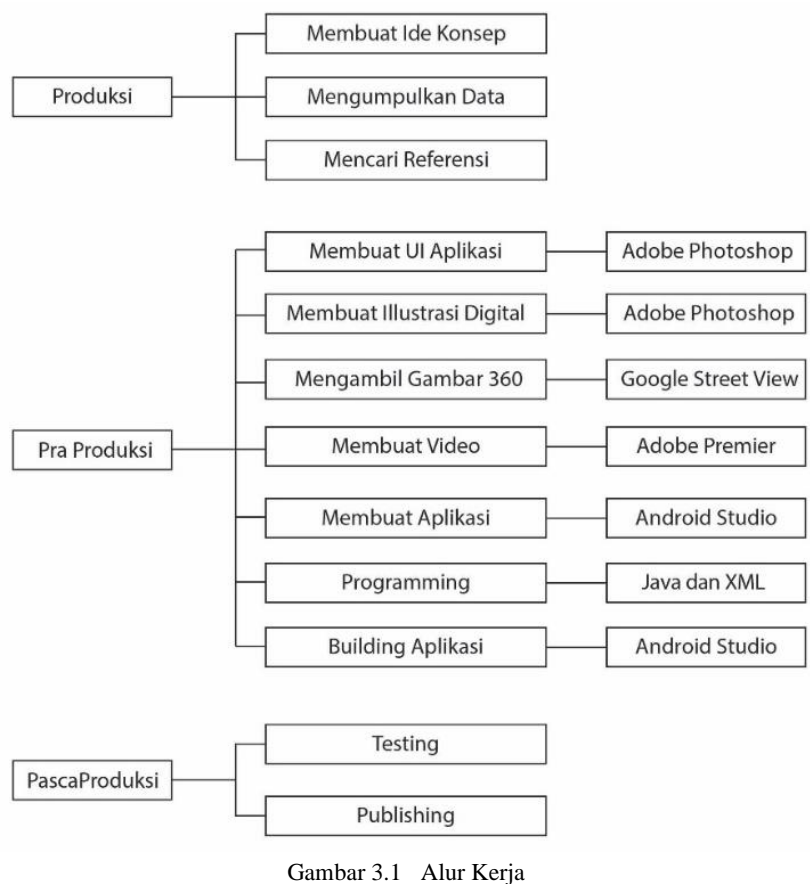

\subsection{Use Case Diagram}

Use case diagram menyatakan visualisasi interaksi yang terjadi antara pengguna (aktor) dengan sistem. Diagram ini bisa menjadi gambaran yang bagus untuk menjelaskan konteks dari sebuah sistem sehingga terlihat jelas batasan dari sistem (Larman, 2005). Berikut ini adalah use case diagram dari aplikasi wisata navigasi berbasis Android yang telah penulis buat.

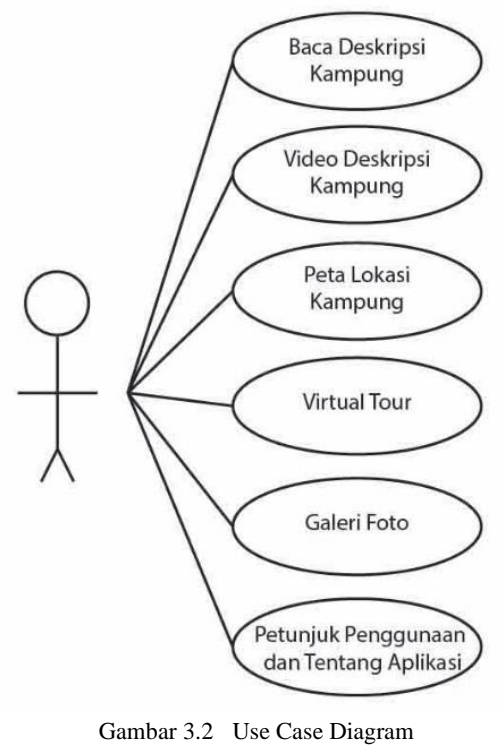

\subsection{Diagram Activity}

Activity diagram main menu ini menggambarkan kejadian dimana pengguna dapat menjalankan aplikasi, mulai dari membuka aplikasi dan menampilkan menu utama kemudian keluar dari aplikasi.

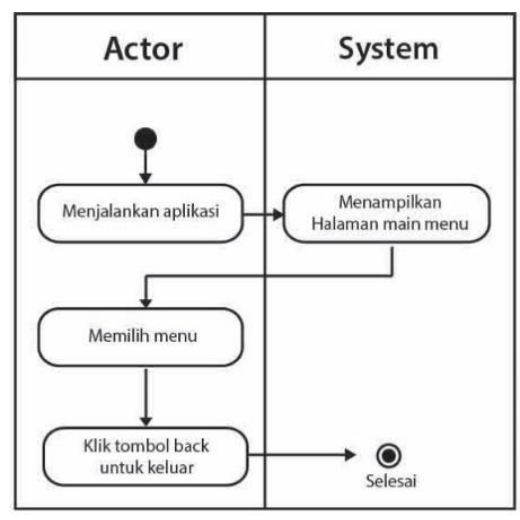

Gambar 3.3 Diagram Acitivity Main Menu

Activity diagram kampung tematik ini menggambarkan kejadian dimana pengguna saat memilih kampung yang akan dilihat, lalu sistem akan menampilkan menu pilihan kampung yang berisikan video pengenalan,deskripsi kampung, peta lokasi, hingga umkm dan transportasi menuju kampung tersebut sehingga pengguna 
dapat langsung membaca informasi mengenai kampung tersebut pada aplikasi.

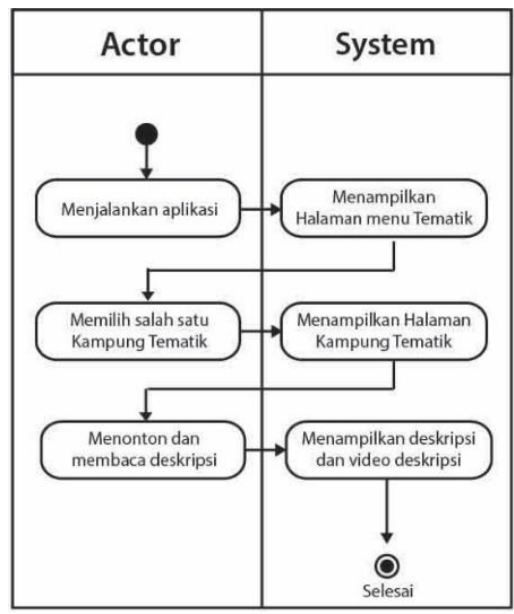

Gambar 3.4 Activity Diagram Kampung Tematik

Activity diagram penanda lokasi ini menggambarkan kejadian dimana pengguna saat memilih lokasi kampung yang dituju, lalu sistem akan menampilkan peta lokasi menuju kampung tersebut sehingga pengguna dapat langsung mengetahui informasi mengenai lokasi kampung tersebut pada aplikasi.

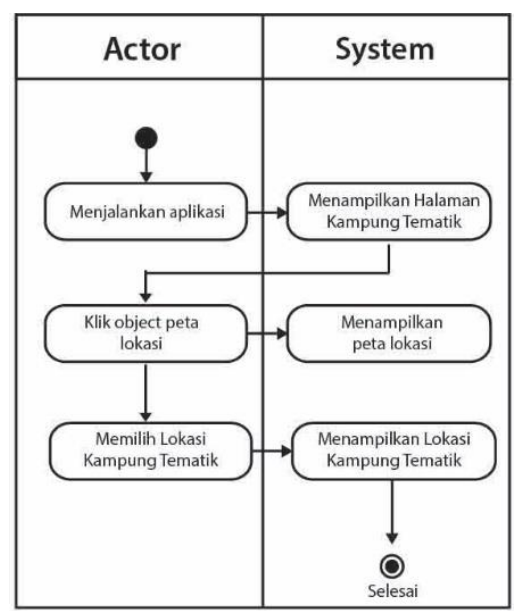

Gambar 3.5 Activity Diagram Peta Lokasi

Activity diagram Virtual Tour ini menggambarkan aktivitas ketika pengguna menekan gambar objek wisata, kemudian sistem akan mengaktifkan halaman VR Camera / Camera 360.

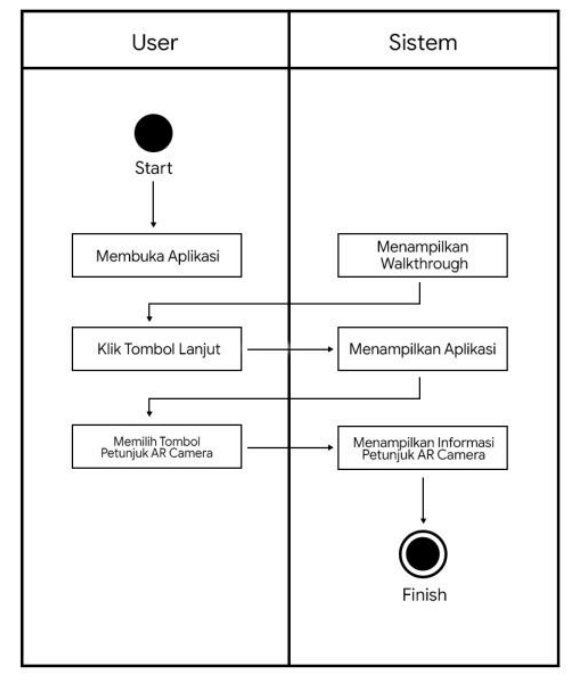

Gambar 3.6 Activity Diagram Virtual Tour

Activity diagram galeri foto ini menggambarkan kejadian dimana pengguna saat menekan button galeri pada main menu, lalu sistem akan menampilkan beberapa objek gambar dimana pengguna bisa melihat gambar tersebut dengan menggeser gambar yang ada di dalam galeri tersebut.

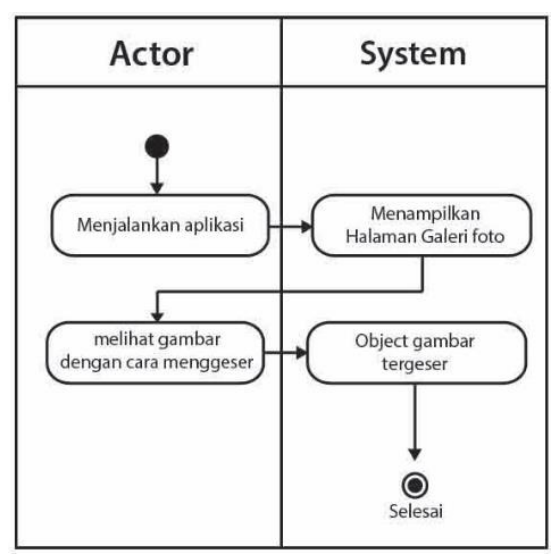

Gambar 3.7 Activity Diagram Galeri Foto

Activity diagram Panduan Aplikasi ini menggambarkan kejadian dimana pengguna saat memilih tombol Panduan Aplikasi, lalu sistem akan menampilkan petunjuk penggunaan dan tentang aplikasi untuk mengetahui informasi dan hak cipta dari aplikasi serta petunjuk menggunakan fitur navigasi dan juga fitur Virtual Tour pada aplikasi. 


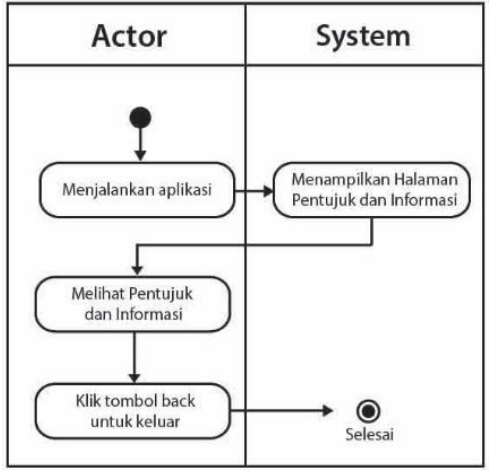

Gambar 3.8 Activity Diagram Panduan Aplikasi

\subsection{Class Diagram}

Class diagram mendiskripsikan jenis-jenis objek dalam sistem dan berbagai macam hubungan statis yang terjadi. Selain itu, class diagram juga menunjukan properti dan operasi sebuah class dan batasan yang terdapat dalam hubunggan dengan objek. Class diagram merupakan alat yang tergolong baik dalam perancangan perangkat lunak. Class diagram dapat membantu pengembang mendapatkan struktur sistem dan menghasilkan rancangan sistem yang baik. Berikut dari class diagram aplikasi wisata navigasi berbasis Android yang telah penulis buat.

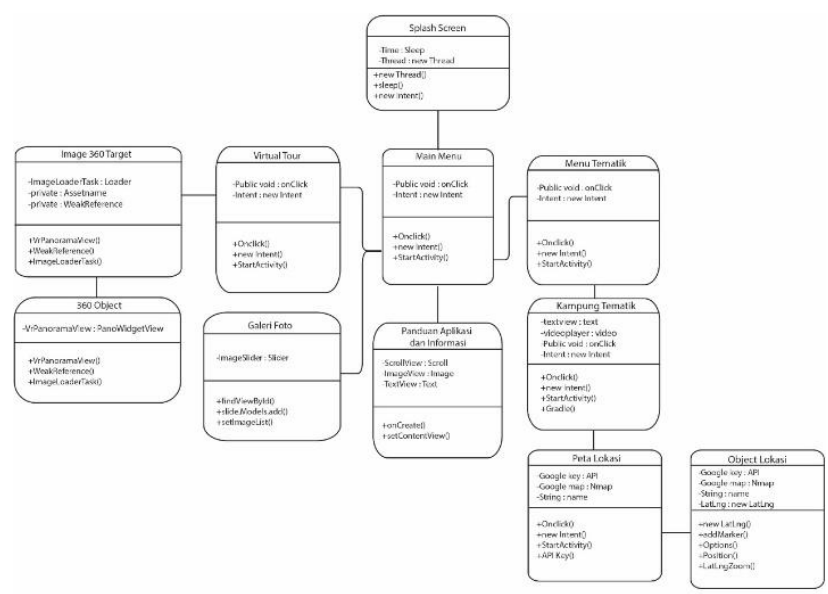

Gambar 3.9 Class Diagram

\subsection{Sequence Diagram}

Sequence diagram adalah diagram yang menggambarkan kolaborasi dinamis antara sejumlah objek. Berikut merupakan sequence diagram pada fitur Virtual Tour dan Peta Lokasi.
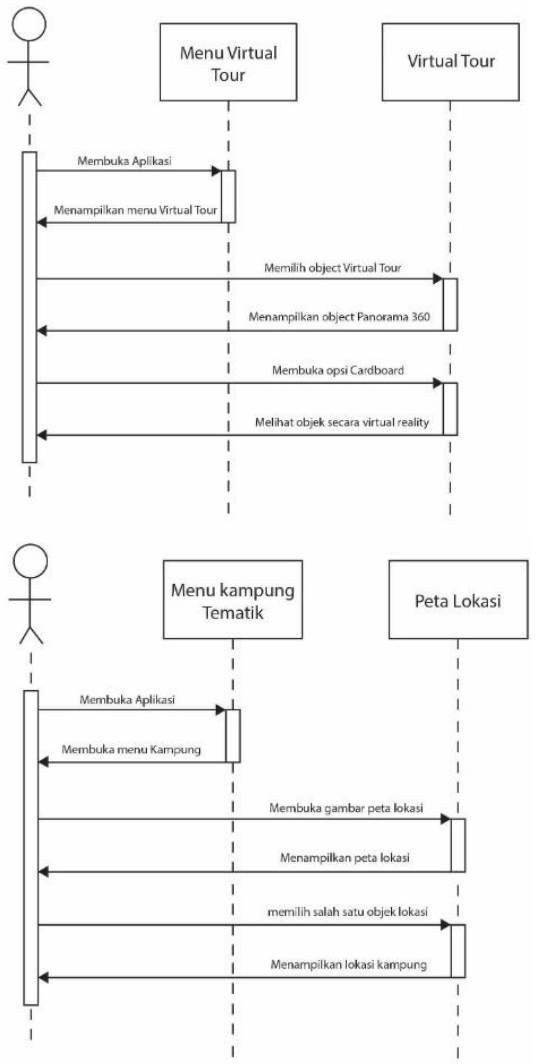

Gambar 3.10 Sequence Diagram Virtual Tour dan Peta Lokasi

\subsection{Perancangan User Interface}

Dalam perancangan Karya Tugas Akhir, penulis membuat rancangan antar menu guna memudahkan pengurutan menu ketika nanti sudah masuk ke tahap pembuatan user interface untuk aplikasi wisata navigasi Berbasis Android. Berikut adalah gambaran struktur menu yang penulis buat dalam bentuk site map:

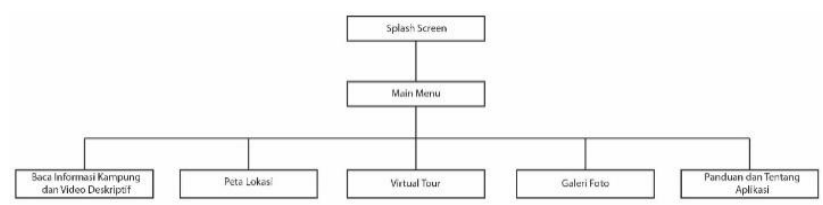

Gambar 3.11 Struktur Menu Aplikasi

\section{HASIL DAN PEMBAHASAN}

\subsection{User Interface}

Berikut adalah rincian ukuran aset UI aplikasi yang penulis desain dengan aplikasi Adobe Photoshop dan Figma 

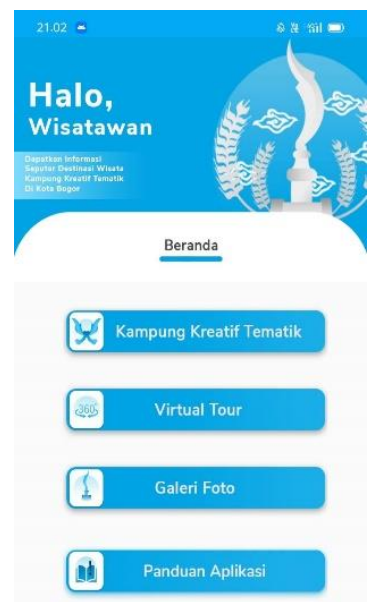

Gambar 3.12 Tampilan Button

\begin{tabular}{|l|l|}
\hline \multicolumn{1}{|c|}{ Aset } & \multicolumn{1}{c|}{ Ukuran } \\
\hline Button Menu Utama & 720 x 135 px \\
\hline Header Aplikasi & $\begin{array}{l}720 \text { x 462 px \& 720 x } \\
293 \text { px }\end{array}$ \\
\hline Logo Aplikasi & 500 x 500 px \\
\hline Button Kampung & 415 x 343 px \\
\hline
\end{tabular}

Tabel 1. Ukuran Tampilan Button

\subsection{Tampilan Motion Graphic}

Video Deskriptif merupakan salah satu fitur yang terdapat pada aplikasi wisata kampung tematik yang erisikan mengenai informasi tentang kampung tersebut.

\begin{tabular}{|l|c|c|}
\hline \multicolumn{3}{|c|}{ Video Deskriptif } \\
\hline \multicolumn{1}{|c|}{ Judul } & Durasi & Ukuran \\
\hline $\begin{array}{l}\text { Kampung } \\
\text { Tematik } \\
\text { Mulyaharja }\end{array}$ & 00:02:49 Detik & $42,7 \mathrm{Mb}$ \\
\hline $\begin{array}{l}\text { Kampung } \\
\text { Tematik Pulo } \\
\text { Geulis }\end{array}$ & $00: 02: 15$ Detik & $23,4 \mathrm{Mb}$ \\
\hline $\begin{array}{l}\text { Kampung } \\
\text { Tematik } \\
\text { Cibuluh }\end{array}$ & $00: 02: 15$ Detik & $26,9 \mathrm{Mb}$ \\
\hline
\end{tabular}

Tabel 2 Tampilan Video Deskriptif

Berikut adalah Background User Interface yang digunakan dan dibuat
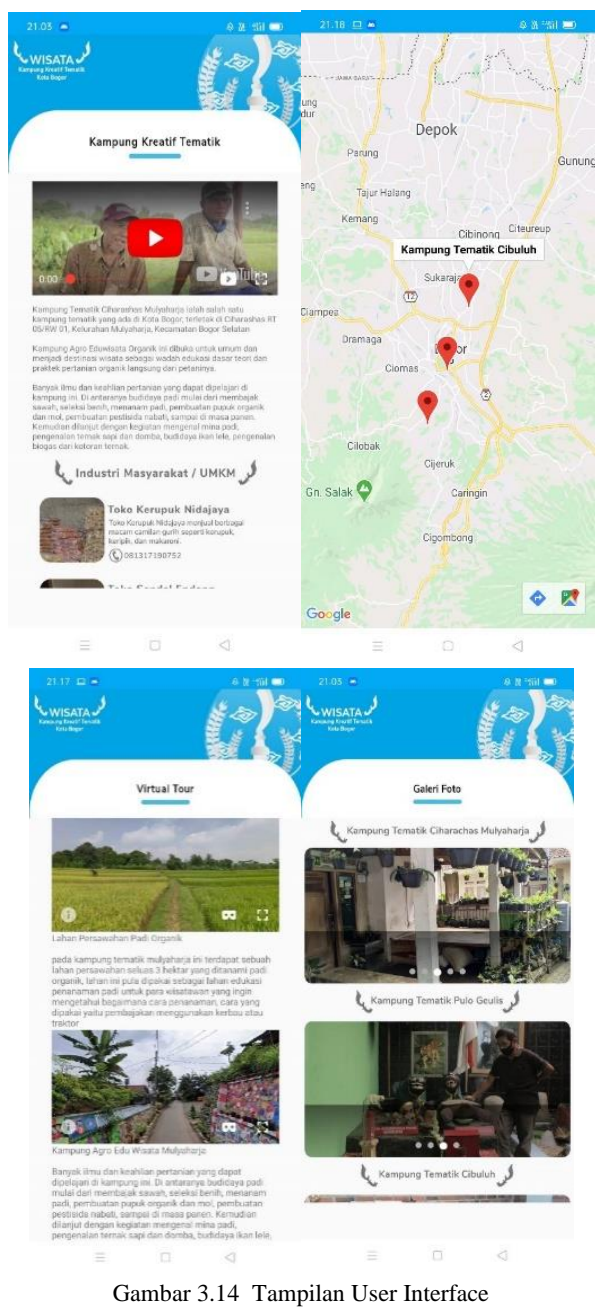

\subsection{Pengujian Aplikasi}

Pada tahap merupakan tahap uji coba aplikasi dengan memasang dan menjalankan aplikasi yang sebelumnya sudah terinstall ke dalam smartphone android. Uji coba aplikasi interaktif ini telah dilakukan di empat perangkat smartphone Android dengan versi sistem operasi yang berbeda. Apabila ada masalah pada aplikasi tersebut akan dilakukan perbaikan (trial and error) hingga aplikasi dapat dijalankan dan berfungsi sebagai mestinya. Berikut adalah spesifikasi perangkat yang digunakan dalam pengujian aplikasi :

Tabel 2. Skenario Pengujian Aplikasi

\section{Developer Test}

\begin{tabular}{|c|c|c|c|c|c|}
\hline \multirow{2}{*}{$\begin{array}{c}\text { Perangkat } \\
\text { Smartphone } \\
\text { Android }\end{array}$} & \multicolumn{5}{|c|}{ Spesifikasi } \\
\hline & Processor & RAM & $\begin{array}{c}\text { Resolusi } \\
\text { Kamera }\end{array}$ & $\begin{array}{c}\text { Resolusi } \\
\text { Layar }\end{array}$ & $\begin{array}{c}\text { OS } \\
\text { Android }\end{array}$ \\
\hline $\begin{array}{l}\text { Perangkat } \\
\text { Developer } \\
\text { (Realme 5i) }\end{array}$ & $\begin{array}{c}\text { Qualcomm } \\
\text { Snapdragon } \\
665\end{array}$ & 4GB & $\begin{array}{c}\text { Single } \\
\text { Camera } \\
8 \mathrm{MP}\end{array}$ & $\begin{array}{c}720 \mathrm{x} \\
1600 \\
\text { pixels }\end{array}$ & $\begin{array}{l}\text { Android } \\
9.0 \mathrm{Pie}\end{array}$ \\
\hline
\end{tabular}

\begin{tabular}{|l|l|l|l|}
\hline Perangkat & Resio & Tampilan Menu & Tampilan \\
Smartphon & Layar & Utama & Halaman \\
e Android & & & Kampung \\
& & & Tematik \\
\hline
\end{tabular}




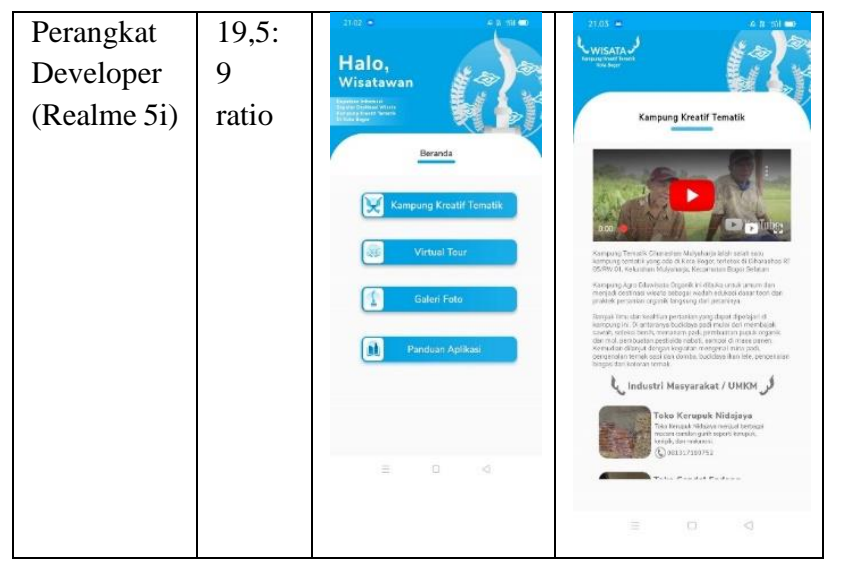

\begin{tabular}{|l|c|}
\hline \multicolumn{1}{|c|}{ Proses Operasi Aplikasi } & Spesifikasi \\
\cline { 2 - 3 } & Perangkat Developer \\
\hline Masuk ke Menu Utama & $5 \mathrm{~s}$ \\
\hline Masuk ke halaman kampung & $1 \mathrm{~s}$ \\
\hline Menampilkan Peta Lokasi & $5 \mathrm{~s}$ \\
\hline Melihat Objek Panorama 360 & $3 \mathrm{~s}$ \\
\hline $\begin{array}{l}\text { Melihat objek panorama 360 } \\
\text { dengan mode Virtual Reality }\end{array}$ & $3 \mathrm{~s}$ \\
\hline $\begin{array}{l}\text { Masuk ke halaman galeri foto } \\
\text { aplikasi ke halaman panduan }\end{array}$ & $1 \mathrm{~s}$ \\
\hline
\end{tabular}

User Test

\begin{tabular}{|c|c|c|c|c|c|}
\hline \multirow{2}{*}{$\begin{array}{c}\text { Perangka } \\
\mathrm{t} \\
\text { Smartph } \\
\text { one } \\
\text { Android }\end{array}$} & \multicolumn{5}{|c|}{ Spesifikasi } \\
\hline & $\begin{array}{c}\text { Processo } \\
\text { r }\end{array}$ & $\begin{array}{c}\text { RA } \\
\mathrm{M}\end{array}$ & $\begin{array}{l}\text { Resolusi } \\
\text { Kamera }\end{array}$ & $\begin{array}{l}\text { Resol } \\
\text { usi } \\
\text { Layar }\end{array}$ & $\begin{array}{c}\text { OS } \\
\text { Androi } \\
\text { d }\end{array}$ \\
\hline $\begin{array}{c}\text { Perangka } \\
\text { t } 1 \\
\text { (vivo } \\
\text { v11 pro) }\end{array}$ & $\begin{array}{c}\text { Qualcom } \\
\text { m } \\
\text { SDM660 } \\
\text { Snapdra } \\
\text { gon } 660\end{array}$ & $\begin{array}{c}6 \mathrm{G} \\
\mathrm{B}\end{array}$ & $\begin{array}{c}12 \mathrm{MP}+5 \\
\mathrm{MP}\end{array}$ & $\begin{array}{c}2340 \\
\mathrm{x} \\
1080 \\
\text { pixels }\end{array}$ & $\begin{array}{c}\text { Funtou } \\
\text { ch OS } \\
4.5\end{array}$ \\
\hline $\begin{array}{c}\text { Perangka } \\
\text { t } 2 \\
\text { (realme } \\
5 \text { pro) }\end{array}$ & $\begin{array}{c}\text { Qualcom } \\
\text { m } \\
\text { SDM712 } \\
\text { Snapdra } \\
\text { gon } 712 \\
\text { AIE } \\
\text { Octa- } \\
\text { core }\end{array}$ & $\begin{array}{c}4 \mathrm{G} \\
\mathrm{B}\end{array}$ & $16 \mathrm{MP}$ & $\begin{array}{c}2340 \\
\mathrm{x} \\
1080 \\
\text { pixels }\end{array}$ & $\begin{array}{c}\text { Androi } \\
\text { d } 9.0 \\
\text { Pie }\end{array}$ \\
\hline
\end{tabular}

\begin{tabular}{|c|c|c|c|c|c|}
\hline $\begin{array}{l}\text { Perangka } \\
\text { t } 3 \\
\text { (samsun } \\
\text { g galaxy } \\
\text { note } 4 \text { ) }\end{array}$ & $\begin{array}{c}\text { Quad- } \\
\text { core } 2.7 \\
\text { GHz } \\
\text { Krait } \\
450\end{array}$ & $\begin{array}{c}3 \mathrm{G} \\
\mathrm{B}\end{array}$ & $16 \mathrm{MP}$ & $\begin{array}{c}1080 \\
x \\
1920 \\
\text { pixels }\end{array}$ & $\begin{array}{l}\text { Androi } \\
\text { d } 4.4 .4 \\
\text { KitKat }\end{array}$ \\
\hline $\begin{array}{c}\text { Perangka } \\
\text { t } 4 \\
\text { (Oppo } \\
\text { A83) }\end{array}$ & $\begin{array}{c}\text { Mediate } \\
\text { k Helio } \\
\text { P23 ( } 16 \\
\text { nm) }\end{array}$ & $\begin{array}{c}2 \mathrm{G} \\
\mathrm{B}\end{array}$ & $13 \mathrm{MP}$ & $\begin{array}{r}1440 \\
\times 720 \\
\text { pixels }\end{array}$ & $\begin{array}{c}\text { Androi } \\
\text { d } 7.0 \\
\text { Nougat }\end{array}$ \\
\hline
\end{tabular}

\begin{tabular}{|c|c|c|c|}
\hline $\begin{array}{l}\text { Perangkat } \\
\text { Smartpho } \\
\text { ne } \\
\text { Android }\end{array}$ & $\begin{array}{l}\text { Resio } \\
\text { Layar }\end{array}$ & $\begin{array}{l}\text { Tampilan Menu } \\
\text { Utama }\end{array}$ & $\begin{array}{l}\text { Tampilan } \\
\text { Halaman } \\
\text { Kampung Tematik }\end{array}$ \\
\hline $\begin{array}{l}\text { Perangkat } \\
1 \\
\text { (vivo v11 } \\
\text { pro) }\end{array}$ & $\begin{array}{l}\text { 19,5:9 } \\
\text { ratio }\end{array}$ & 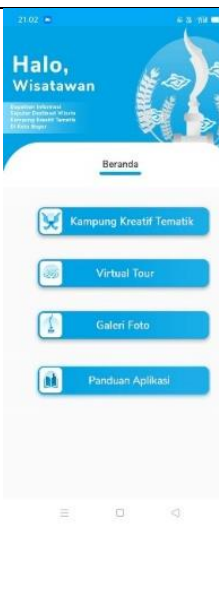 & 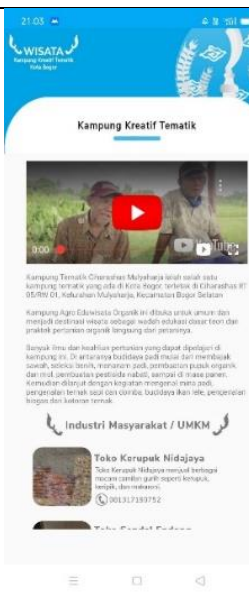 \\
\hline $\begin{array}{l}\text { Perangkat } \\
2 \\
\text { (realme } 5 \\
\text { pro) }\end{array}$ & $\begin{array}{l}19,5: 9 \\
\text { ratio }\end{array}$ & 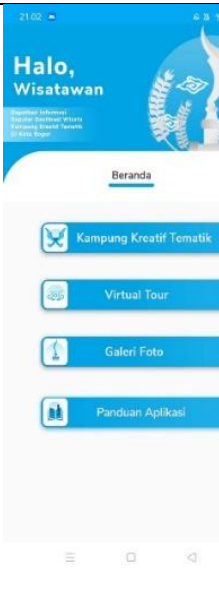 & 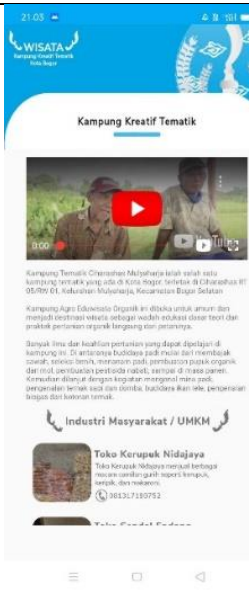 \\
\hline
\end{tabular}




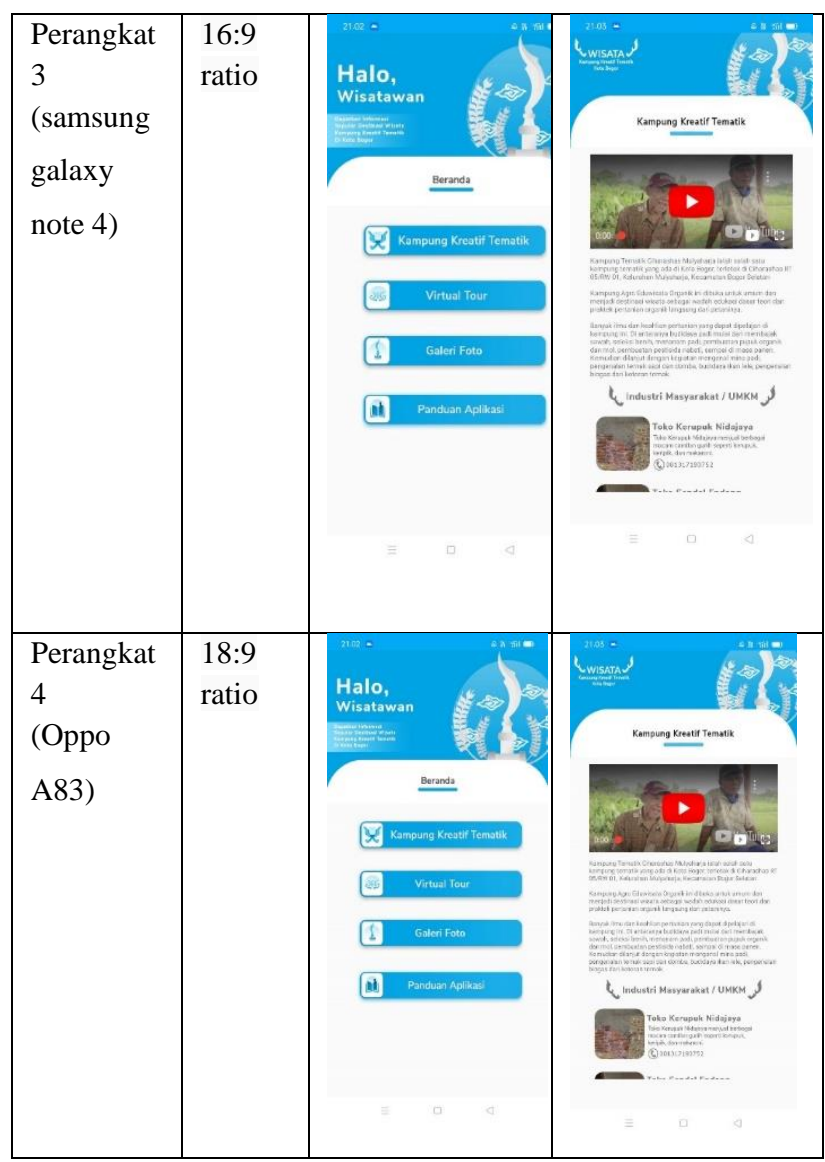

Setelah seluruh perangkat disiapkan, kemudian dilakukan instalasi aplikasi pada masing-masing perangkat. Selain instalasi selesai, maka akan dilakukan pengujian berdasarkan kecepatan aplikasi berdasarkan waktu/detik pada saat aplikasi digunakan mulai dari ke fitur melihat informasi, video deskriptif, peta lokasi, virtual tour, galeri, panduan aplikasi dan kembali ke menu utama. Berikut adalah hasil uji coba aplikasi pada empat perangkat Android.

\begin{tabular}{|l|c|c|c|c|}
\hline \multicolumn{1}{|c|}{\begin{tabular}{c} 
Proses $\begin{array}{c}\text { Operasi } \\
\text { Aplikasi }\end{array}$ \\
\cline { 2 - 5 }
\end{tabular}} & $\begin{array}{c}\text { Perangk } \\
\text { at } 1\end{array}$ & $\begin{array}{c}\text { Perangk } \\
\text { at 2 }\end{array}$ & $\begin{array}{c}\text { Perangk } \\
\text { at 3 }\end{array}$ & $\begin{array}{c}\text { Perangk } \\
\text { at } 4\end{array}$ \\
\hline $\begin{array}{l}\text { Masuk ke } \\
\text { Menu } \\
\text { Utama }\end{array}$ & $5 \mathrm{~s}$ & $5 \mathrm{~s}$ & $6 \mathrm{~s}$ & $6 \mathrm{~s}$ \\
\hline $\begin{array}{l}\text { Masuk ke } \\
\text { halaman } \\
\text { kampung }\end{array}$ & $1 \mathrm{~s}$ & $1 \mathrm{~s}$ & $2 \mathrm{~s}$ & $2 \mathrm{~s}$ \\
\hline $\begin{array}{l}\text { Menampilka } \\
\mathrm{n}\end{array}$ & $5 \mathrm{~s}$ & $5 \mathrm{~s}$ & $5 \mathrm{~s}$ & $7 \mathrm{~s}$ \\
Lokasi & & $3 \mathrm{~s}$ & $7 \mathrm{~s}$ & $8 \mathrm{~s}$ \\
\hline $\begin{array}{l}\text { Melihat } \\
\text { Objek }\end{array}$ & & & & \\
\hline
\end{tabular}

\begin{tabular}{|l|c|c|c|c|}
\hline $\begin{array}{l}\text { Panorama } \\
360\end{array}$ & & & & \\
\hline $\begin{array}{l}\text { Melihat } \\
\text { objek } \\
\text { panorama } \\
360 \text { dengan } \\
\text { mode } \\
\begin{array}{l}\text { Virtual } \\
\text { Reality }\end{array}\end{array}$ & $3 \mathrm{~s}$ & $3 \mathrm{~s}$ & $3 \mathrm{~s}$ & $4 \mathrm{~s}$ \\
\hline $\begin{array}{l}\text { Masuk ke } \\
\text { halaman } \\
\text { galeri foto }\end{array}$ & $1 \mathrm{~s}$ & $1 \mathrm{~s}$ & $2 \mathrm{~s}$ & $2 \mathrm{~s}$ \\
\hline $\begin{array}{l}\text { Masuk ke } \\
\text { halaman } \\
\text { panduan } \\
\text { aplikasi }\end{array}$ & $1 \mathrm{~s}$ & $1 \mathrm{~s}$ & $2 \mathrm{~s}$ & $2 \mathrm{~s}$ \\
\hline
\end{tabular}

Berdasarkan hasil dari pengujian aplikasi pada perangkat Android, maka aplikasi dapat berjalan dengan baik sesuai dengan fungsinya pada semua perangkat. Hal ini didukung dengan processor yang sesuai. Tiap tiap perangkat dapat membuka maps dan virtual tour dengan baik sehingga tidak terjadi delay dan juga object panorama langsung terlihat. Pada perangkat 2 dan 3 mengalami stretch karena perbedaan resolusi sehingga ada beberapa tombol yang terpotong, tetapi masih bisa digunakan dengan baik. Dapat disimpulkan bahwa standar spesifikasi smartphone yang sesuai dengan standar yang telah disarankan juga mempengaruhi berjalan atau tidaknya aplikasi ini. Dan aplikasi dapat berjalan sesuai dengan fungsinya pada resolusi layar 19,5:9

\section{KESIMPULAN DAN SARAN}

\subsection{Kesimpulan}

Pada pembuatan Aplikasi navigasi mengenai Kampung Kreatif Tematik pada Smart Branding Kota Bogor berbasis Android ini terdapat beberapa kesimpulan, Berikut kesimpulan dari Karya Tugas Akhir ini:

1. Aplikasi navigasi ini bisa menjadi sebuah inovasi baru yang dapat dipakai sebagai media informasi mengenai Kampung Kreatif Tematik dengan penambahan sebuah fitur peta lokasi dan fitur virtual tour, sehingga media tersebut lebih bersifat interaktif dipakai.

2. Dengan adanya system navigasi yang dipadukan fitur virtual tour, wisatawan akan lebih mudah mengetahui 
lokasi object wisata dan mudah untuk mengetahui lokas object secara virtual.

3. Dengan dibuatnya aplikasi wisata bersistem navigasi dengan fitur virtual tour dapat bisa menggantikan media informasi cetak seperti booklet yang terlihat monoton dan membosankan dimata masyarakat Kota Bogor.

\subsection{Saran}

Beberapa hal yang dapat dikembangkan dari aplikasi wisata navigasi Kampung Kreatif Tematik adalah:

1. Fitur informasi seperti umkm/industry masyarakat dan transportasi masih dapat dikembangkan untuk dibuat lebih interaktif lagi

2. Fitur galeri foto masih dapat dikembangkan agar object foto dapat terlihat dengan fullscreen

3. Sistem operasi yang dikembangkan selain Android, dapat juga dikembangkan pada iOS.

\section{DAFTAR PUSTAKA}

Rahmandanu, M. A. (2015). Rancang Bangun Aplikasi Pariwisata Kabupaten Klaten Berbasis Android Dengan Metode Extreme Programming

Ibrahim. (2001). Association for Education Communication Technologi.

Meg, C. (2011). Nicola Building Virtual Tour; Considering simulation in the equity of experience concept.

Dusan J, Rogue, Antonio, Leuski, Anton, Morie, Jacki, Traum \& David. (2009). A Virtual Tour Guide for Virtual Worlds.

Aji, G. S. (2018). Pembangunan Virtual Tour Sebagai Alternatif Media Promosi Dengan Memanfaatkan Fitur Panorama Pada Kamera Digital.

Diskominfo. (2017). Master Plan Smart City Kota Bogor. Bogor: Diskominfo.

Diskominfo. (2019). Diakses dari https://kominfo.kotabogor.go.id/

Disparbud. (2019). Diakses dari https://disparbud.kotabogor.go.id/index.php/parawisata/album/D ATA-DESTINASI-OBJEK-WISATA

Diskominfo. (2019). Diakses dari https://www.kominfo.go.id/content/detail/11656/langkahmenuju-100-smart-city/0/sorotan_media

Herawati, N. (2018). Mengenal Lebih Dekat Diskominfo dalam Pengembangan Smart City Kota Bogor. Bogor: Dinas Komunikasi dan Informatika Kota Bogor.

\section{BIODATA PENULIS}

\section{Raden Agung Pradana Rusdian}

Lahir pada 15 April 1999 di Kota Bogor. Saya adalah mahasiswa di program studi Multimedia dari Politeknik Negeri Media Kreatif Jakarta. Saya mulai menempuh pendidikan saya di Polimedia pada tahun 2017. Dan kiat aktif dalam organisasi mahasiswa polimedia. organisasi yang saya ikuti diantaranya adalah Himpunan Mahasiswa Multimedia. 